\title{
Upaya Peningkatan Harga Diri Remaja Dengan Kesehatan Reproduksi
}

\author{
Susanti ${ }^{1}$ \\ ${ }^{1}$ Program Studi S1 Kebidanan \\ STIKES Al-Irsyad Al-Islamiyyah Cilacap, Jl. Cerme 24 Sidanegara Cilacap \\ Email korespondensi santirnj@gmail.com
}

\begin{abstract}
Abstrak
Harga diri dan perilaku berisiko terhadap kesehatan pada remaja. Hipotesis yang diajukan adalah ada hubungan negatif antara harga diri dengan perilaku berisiko terhadap kesehatan pada remaja. Mayoritas pola perilaku berisiko yang dilakukan adalah merokok, minum alkohol, melakukan hubungan seksual pranikah, dan penyalahgunaan narkoba Metode Pelaksanaan kegiatan ini adalah melakukan pre test dengan menggali pengetahuan, pelaksanaan penyuluhan NAPZA dan HIV/AIDS dan melakukan post test dengan beberapa pertanyaan. Hasil luaran setelah dilakukan kegiatan penyuluhan ini adalah terjadinya peningkatan pengetahuan dengan dibuktikan dengan dari lima pertanyaan tentang NAPZA dan HIV/AIDS terkait NAPZA, HIV/AIDS, bahaya dan pencegahannya siswa-siswi dapat menjawab dengan benar.
\end{abstract}

Kata Kunci : Harga Diri, Kesehatan Reproduksi Remaja, Remaja

\begin{abstract}
Self-esteem and health risk behaviors in adolescents. The hypothesis proposed is that there is a negative relationship between self-esteem and risk behaviors for health in adolescents. The majority of risk behavior patterns carried out are smoking, drinking alcohol, engaging in premarital sexual relations, and drug abuse. The method of this activity is to conduct a pre-test by exploring knowledge, conducting drug education and HIV / AIDS counseling and conducting a post-test with several questions. The results of the outcomes after the outreach activities were an increase in knowledge with evidence from five questions about drugs and HIV / AIDS related to drugs, HIV / AIDS, the dangers and prevention of students being able to answer correctly.
\end{abstract}

Keywords : Self-Esteem, Adolescent Reproductive Health, Youth

\section{PENDAHULUAN}

Remaja adalah mereka yang berada pada tahap transisi antara masa kanakkanak dan dewasa. Batasan usia remaja menurut WHO adalah 12 sampai 24 tahun. Menurut Menteri Kesehatan RI tahun 2010, batas usia remaja adalah antara 10 sampai 19 tahun dan belum kawin. Pada masa remaja berbagai perubahan terjadi baik perubahan hormonal, fisik, psikologis maupun sosial, diantaranya adalah pengaruh lingkungan. Perubahan ini terjadi dengan sangat cepat dan terkadang tanpa kita sadari. 
Masa remaja adalah kunci tahap perkembangan untuk membentuk kesehatan di masa dewasa, oleh sebab itu diharapkan remaja Indonesia dapat mengendalikan dirinya untuk mengurangi perilaku berisiko terhadap kesehatan yang dapat mengakibatkan munculnya berbagai penyakit atau bahkan kematian. Remaja diharapkan mampu memilih dan menentukan aktivitas-aktivitas yang bermanfaat sehingga nantinya dapat tumbuh sebagai dewasa yang sehat dan berguna bagi dirinya serta masyarakat di sekitarnya.

Telah dicatat dan didokumentasikan dengan baik bahwa perilaku berisiko terhadap kesehatan sebagian besar dimulai selama tahun-tahun remaja dan permulaan perilaku berisiko secara bertahap terjadi pada usia muda. Berdasarkan skala YRBSS (Youth Risk Behavior Surveillance System) yang dibuat oleh CDC (Brener et al., 2013), perilaku berisiko terhadap kesehatan merupakan perilaku yang saling terkait dan dapat dicegah, yang berkontribusi terhadap penyebab utama angka kesakitan dan kematian di antara remaja dan dewasa.

Remaja yang berusia 14 sampai 18 tahun, menunjukkan prevalensi yang sangat tinggi dalam penggunaan alkohol. $77 \%$ remaja pernah minum minuman beralkohol, dan di antaranya, 17\% dari remaja melaporkan minum alkohol setiap hari atau 1-2 kali per minggu (Kim, 2011)

Departemen Kesehatan Republik Indonesia mendefinisikan remaja berisiko sebagai remaja yang pernah melakukan perilaku yang berisiko terhadap kesehatan. Berdasarkan hasil penelitian, sebanyak 55,2 \% remaja pernah melakukan perilaku berisiko. Secara berurutan, mayoritas pola perilaku berisiko yang dilakukan adalah merokok, minum alkohol, melakukan hubungan seksual pranikah, dan penyalahgunaan narkoba. Hasil analisis Survey Kesehatan Reproduksi remaja Indonesia (SKRRI) 2007 menunjukkan peningkatan prevalensi perilaku berisiko baik di kalangan remaja laki-laki maupun remaja perempuan, jika dibandingkan dengan hasil SKRRI 2002-2003 (Heny and Sugiharti, 2011). Hal ini diperkuat oleh penelitian (Indahwati, Wati and Wulandari, 2017; Susanti, 2017) bahwa dari 319 penderita HIV/AIDS yang merupakan usia 10-14 tahun sebanyak 1 orang (0,3\%), dan usia 15-19 tahun sebanyak 8 orang (2,5\%). Dalam beberapa tahun terakhir, telah terjadi pergeseran ke arah penelitian yang didasarkan pada teori dan praktek yang didukung secara empiris, yang mewajibkan perawatan perilaku kesehatan 
yang berfokus pada rentang interaksi yang luas dengan perilaku kesehatan yang negatif dan kecenderungan psikologis pada remaja. Dalam hal ini, sebuah penelitian yang dilakukan oleh Kim (2011) menunjukkan bahwa terdapat tiga variabel psikologis (multidimensional health locus of control, efikasi diri, dan harga diri) yang secara signifikan berkorelasi dengan perilaku berisiko terhadap kesehatan. Korelasi yang sudah teridentifikasi ini memungkinkan untuk eksplorasi lebih lanjut tentang kemungkinan hubungan antara variabel psikologis dan perilaku berisiko terhadap kesehatan. Temuan ini didukung oleh penelitian sebelumnya oleh (Kim, 2011) menyatakan bahwa efikasi diri dan harga diri adalah prediktor signifikan dari aktivitas fisik dan kesehatan mental. Baru-baru ini, George dan rekan-rekannya (Kim, 2011) juga mendukung hubungan antara perilaku berisiko terhadap kesehatan dan variabel psikologis, dan menunjukkan bahwa harga diri dan efikasi diri memiliki pengaruh signifikan terhadap perilaku merokok dan minum alkohol.

Salah satu perkembangan psikologis yang dialami oleh remaja adalah perkembangan sosio-emosi yang salah satunya adalah harga diri, yang merupakan keseluruhan cara yang digunakan untuk mengevaluasi diri kita, dimana harga diri merupakan perbandingan antara ideal-self dengan real-self. (W, 2012). Permasalahan yang dapat terjadi pada remaja adalah adanya pergaulan bebas, adanya kehamilan pada remaja sehingga menyebabkan kehamilan yang tidak diinginkan, dan penyakit infeksi menular seksual (HV/AIDS) dan NAPZA.

Berdasarakan latar belakang di atas maka akan diadakan kegiatan penyuluhan kesehatan reproduksi remaja sebagai upaya meningkatkan harga diri remaja.

\section{MASALAH}

Permasalahan yang ada pada mitra yang ditemui tim adalah kurangnya pengetahuan siswa tentang NAPZA dan HIV/AIDS dan kurangnya kepercayaan diri siswa. Berdasarkan masalah tersebut, tujuan pengabdian ini adalah untuk mengetahui pengetahuan remaja tentang kesehatan reproduksi khususnya NAPZA dan HIV/AIDS serta untuk mengetahui kepercayaan diri remaja. 


\section{METODE}

1) Cara Pemecahan Masalah

Pengabdian ini dilaksanakan dengan metode:

a. Berkoordinasi dengan pihak sekolah MAN Purbalingga sebagai tempat pengabdian masyarakat.

b. Penggalian pengetahuan siswa tentang kesehatan reproduksi remaja terkait dengan NAPZA dan HIV/AIDS

c. Pemberian materi tentang NAPZA dan HIV/AIDS

d. Meningkatkan kepercayaan diri remaja dengan melakukan evaluasi terhadap beberapa siswa untuk maju ke depan kelas untuk menjelaskan materi NAPZA dan HIV/AIDS.

e. Evaluasi Tentang NAPZA dan HIV/AIDS
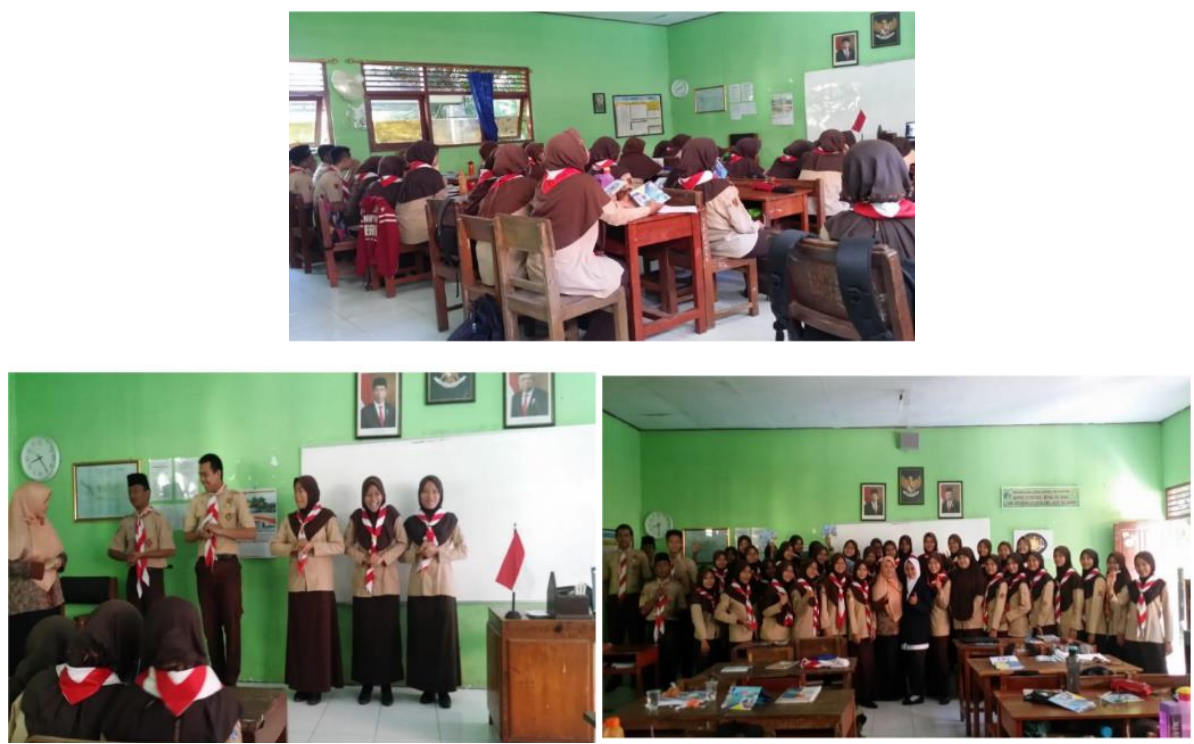

Gambar 3.1 Proses pemberian materi Pengabdian

2) Lokasi, Waktu dan Durasi Kegiatan

Lokasi di MAN Purbalingga kegiatan dilaksanakan pada tanggal 18 Januari 2020, lama kegiatan masing - masing 60 menit.

\section{HASIL DAN PEMBAHASAN}

\section{1) Hasil}

Proses pengabdian masyarakat dimulai dengan diperolehnya perijinan dari Sekolah MAN Purbalingga. Pelaksanaan pengabdian masyarakat ini dilaksanakan satu hari pada hari Sabtu, tanggal 18 Januari 2020 bertempat di 
sekolah MAN Purbalingga mulai dari jam 07.30 - 10.00 WIB dengan jumlah peserta yang didapatkan adalah 30 siswa.

Kegiatan penyuluhan dimulai dengan pembukaan dan kemudian pemberian materi sebelumnya pemateri melakukan penggalian tingkat pengetahuan siswa tentang sejauh mana siswa mengetahui tentang pentingnya harga diri, NAPZA dan HIV/AIDS. Hal ini juga untuk menggali tingkat kepercayaan diri siswa di depan teman - temannya, dan hanya 2 siswa yang berani untuk menjawab pertanyaan tentang NAPZA dan HIV/AIDS. Keberhasilan kegiatan pelatihan ini disebabkan kooperatifnya peserta mulai dari awal pelatihan sampai selesai. Alasan dari aktifnya partisipasi peserta tersebut adalah keingintahuan peserta tentang pentingnya pencegahan dari NAPZA dan HIV/AIDS.

Berdasarkan hasil pengamatan dan diskusi selama kegiatan penyuluhan materi maupun respon peserta terhadap semua materi yang disampaikan baik yang teknis 10 maupun yang non teknis cukup baik, dan dari hasil evaluasi sebelum penyampaian materi dan setelah penyampaian materi respon peserta cukup baik hal ini ditandai dengan evaluasi dari lima pertanyaan tentang NAPZA dan HIV/AIDS siswa dapat menjawab pertanyaan dengan baik. Siswa yang diawal sebelum diberikan penyuluhan terkait kesehatan reproduksi remaja siswa belum dapat menjawab beberapa pertanyaan contohnya tentang apa bahayanya dan cara pencegahan HIV/AIDS dan NAPZA.

Pengetahuan siswa sebelum dilakukan penyuluhan yang memiliki tingkat pengetahuan cukup kemungkinan hal ini dipengaruhi oleh sumber informasi yang siswa dapatkan, hal ini diperkuat sumber informasi yang mereka dapatkan berasal dari internet. Hal ini yang dimungkinkan siswa tidak mendapatkan informasi yang benar tentang NAPZA dan HIV/AIDS.

Dan berdasarkan informasi dari guru BK sekolah bahwa kegiatan penyuluhan tentang kesehatan reproduksi belum rutin dilakasankan di sekolah. Sehingga hal ini juga dimungkinkan menjadi sebab siswa masih kurang mengerti tentang kesehatan khususnya materi tentang apa itu NAPZA dan HIV/AIDS, gejala dan tanda, serta bagaimana pencegahannya. 
Peningkatan kepercayaan diri siswa meningkat dengan dibuktikan dengan 5 siswa memiliki keberanian untuk menjelaskan kembali materi tentang NAPZA dan HIV/AIDS di depan kelas dengan performa yang baik.

\section{2) Pembahasan}

Peningkatan pengetahuan siswa mengenai HIV dan AIDS penting untuk dilakukan dengan tujuan agar siswa dapat melakukan pencegahan penularan HIV dan AIDS dan mengurangi stigma AIDS yang ada di masyarakat, serta bahanya NAPZA.

Penyuluhan mengenai NAPZA, HIV dan AIDS yaitu pengertian, cara penularan, cara pencegahan, pemeriksaan, pengobatan dan perawatan orang dengan HIV/AIDS (Odha) diberikan oleh Narasumber yang juga adalah dosen di Prodi S1 Kebidanan STIKES Al-Irsyad Al-Islmaiyyah Cilacap yaitu Susanti, M.Keb. Melalui penyuluhan ini dapat membuka wawasan siswa dan juga guru BK yang berkesempatan hadir tentang pentingnya pendidikan kesehatan reproduksi utamanya mengenai HIV dan AIDS. Diharapkan generasi muda ini dapat memahami tentang cara penularan HIV dan mengurangi stigma yang buruk pada penderita HIV dan AIDS, menularkan informasi ini kepada rekan sebayanya dan masyarakat pada umumnya. Pada saat penyuluhan peserta nampak sangat antusias dengan informasi yang diberikan, yang tercermin dalam pertanyaan yang diajukan. Dan beberapa siswa bisa menjelaskan di depan kelas tentang NAPZA dan HIV/AIDS pada teman-temannya.

Hal ini juga diperkuat oleh hasi penelitian yang dilakukan oleh (Asfar and Sri, 2018) bahwa ada pengaruh penyuluhan kesehatan sebelum dan sesudah terhadap tingkat pengetahuan tentang penyakit HIV/AIDS dengan nilai $\mathrm{p}$ value $=0,000$ $(\alpha<0,05)$. Dan Ada pengaruh penyuluhan kesehatan sebelum dan sesudah terhadap sikap tentang penyakit HIV/AIDS di SMP BAZNAS Prov.Sul-Sel. Hal ini ditunjukkan dengan nilai $\rho$ value $=0,035(\alpha<0,05)$.

Selain hal diatas sekolah MAN Purbalingga adalah sekolah yang berbasis keagamaan yang memiliki kurikulum tentang ke-Islaman dengan mata pelajaran keagamaan lebih banyak dibandingkan dengan sekolah biasa sehingga siswasiswinya memiliki pengetahuan dan pemahaman keagamaan yang lebih bagus, 
dimana setelah dilakukan wawancara siswa-siswi tidak ada yang minum-minuman keras dan menggunakan narkoba.

\section{KESIMPULAN}

Kesimpulan dari kegiatan penyuluhan kesehatan ini meningkatkan pengetahuan siswa-siswi tentang NAPZA dan HIV/AIDS, dan kepercayaan diri siswa siswi meningkat.

\section{DAFTAR PUSTAKA}

Asfar, A. and Sri, A. W. O. (2018) 'Pengaruh Penyuluhan Kesehatan Terhadap Tingkat Pengetahuan Dan Sikap Tentang Penyakit Hiv/Aids Di SMP Baznas Provinsi Sulawesi Selatan', Journal Of Islamic Nursing, 3(1).

Brener, N. D. et al. (2013) 'Methodology of the youth risk behavior surveillance system - 2013', MMWR Recommendations and Reports.

Heny, L. and Sugiharti (2011) 'Perilaku Berisiko Remaja di Indonesia Menurut Survey Kesehatan Reproduksi Remaja Remaja Indonesia (SKRRI) Tahun 2007', Jurnal Kesehatan Reproduksi, 1(3), pp. 136-144. Available at: https://media.neliti.com/media/publications/105615-ID-none.pdf.

Indahwati, L., Wati, L. R. and Wulandari, D. T. (2017) 'Usia dan Pengalaman KB Berhubungan dengan Pemilihan Metode Kontasepsi, Fakultas Kedokteran Universitas Brawijaya', Journal of Issues in Midwifery.

Kim, Y. (2011) 'Adolescent's Health Behaviours and Its Associations with Psychological Variables.', Journal of Public Health, 19(4), pp. 205-209. Available at: https://www.ncbi.nlm.nih.gov/pubmed/22432395.

Susanti (2017) 'Karakteristik Penderita HIV/AIDS Di Klinik Vct Rumah Sakit Umum Daerah Cilacap Tahun 2013-2016', Viva medika : Jurnal Kesehatan, Kebidanan dan keperawatan, 10(2), pp. 20-27. doi: Karakteristik Penderita HIV/AIDS Di Klinik Vct Rumah Sakit Umum Daerah Cilacap Tahun 20132016.

W, S. J. (2012) Life-Span Development (Perkembangan Masa Hidup Edisi 13). 1st edn. Jakarta: Erlangga. 